\author{
Jo Seldeslachts * \\ Joseph A. Clougherty ** \\ Pedro Pita Barros ***
}

\title{
Remedy for Now but Prohibit for Tomorrow: \\ The Deterrence Effects of Merger Policy Tools
}

* WZB - Wissenschaftszentrum Berlin

** WZB - Wissenschaftszentrum Berlin and CEPR

*** New University of Lisbon

SP || $2007-02$

February 2007

ISSN Nr. $0722-6748$

Research Area

Markets and Politics

Research Unit

Competitiveness and Industrial Change
Schwerpunkt II

Märkte und Politik

Abteilung

Wettbewerbsfähigkeit und industrieller Wandel 
Zitierweise/Citation:

Jo Seldeslachts, Joseph A. Clougherty, and Pedro Pita Barros, Remedy for Now but Prohibit for Tomorrow: The Deterrence Effects of Merger Policy Tools, Discussion Paper SP II 2007 - 02, Wissenschaftszentrum Berlin, 2007.

Wissenschaftszentrum Berlin für Sozialforschung $\mathrm{gGmbH}$,

Reichpietschufer 50, 10785 Berlin, Germany, Tel. (030) 25491 - 0

Internet: www.wzb.eu 


\section{Remedy for Now but Prohibit for Tomorrow: The Deterrence Effects of Merger Policy Tools*}

by Jo Seldeslachts, Joseph A. Clougherty, and Pedro Pita Barros

Antitrust policy involves not just the regulation of anti-competitive behavior, but also an important deterrence effect. Neither scholars nor policymakers have fully researched the deterrence effects of merger policy tools, as they have been unable to empirically measure these effects. We consider the ability of different antitrust actions - Prohibitions, Remedies, and Monitorings - to deter firms from engaging in mergers. We employ cross-jurisdiction/pan-time data on merger policy to empirically estimate the impact of antitust actions on future merger frequencies. We find merger prohibitions to lead to decreased merger notifications in subsequent periods, and remedies to weakly increase future merger notifications: in other words, prohibitions involve a deterrence effect but remedies do not.

Keywords: merger policy tools, deterrence effects, cross-section/time-series data JEL Classification: L40, L49, K21

We wish to thank Jan De Loecker, Robert Feinberg, Michal Grajek, and Lars-Hendrik Röller, and especially Tomaso Duso for helpful discussions; participants at the ASSET conference in Lisbon, City University London, CEPR Applied IO workshop in Madeira, CPIM-CEPR workshop in Brussels, DIW in Berlin, IIOC conference in Boston, SFB seminar in Mannheim, Spanish IO workshop in Barcelona, Trinity College Dublin, University of Paris Pantheon-Sorbonne, and IUI in Stockholm for helpful comments; Claudia Alves and Enno Schroeder for excellent research assistance. Jo Seldeslachts recognizes financial assistance from the EC 5th framework program: RTN (HPRN-CT-2002-00224) and is, as well, the contact author. 


\section{Auflagen heute, Untersagung morgen: Abschreckungswirkung von Wettbewerbs-intrumenten}

by Jo Seldeslachts, Joseph A. Clougherty, and Pedro Pita Barros

Wettbewerbspolitik ist nicht nur Regulierung von wettbewerbsfeindlichem Verhalten, sondern hat auch eine wesentliche Abschreckungswirkung. Weder Wissenschaftler noch politische Entscheidungsträger haben die Abschreckungswirkung von Wettbewerbspolitik vollständig untersucht, da es sehr schwierig ist diese Wirkung empirisch nachzuweisen. Wir untersuchen die Wirkung verschiedener wettbewerbspolitischer Maßnahmen - Untersagung, Auflagen und Monitoring - um Unternehmen von Zusammenschlüssen abzuhalten. Wir nutzen einen Panel-Datensatz, um den Einfluss von Wettbewerbspolitik auf die künftige Anzahl von Firmenzusammenschlüssen zu bewerten. Wir zeigen, dass die Untersagung von Zusammenschlüssen die Fusionsankündigung in der Zukunft reduziert, und dass Fusionsauflagen künftige Ankündigungen schwach ansteigen lassen. Anders gesagt: Untersagungen haben eine führen zu Abschreckungswirkung, Auflagen nicht. 


\title{
Remedy for Now but Prohibit for Tomorrow: \\ The Deterrence Effects of Merger Policy Tools
}

\author{
Jo Seldeslachts * \\ Wissenschaftszentrum Berlin (WZB) \\ Reichpietschufer 50, 10785 Berlin, Germany \\ E-Mail : Seldeslachts@wz-berlin.de \\ Tel: +49 3025491404 \\ Joseph A. Clougherty \\ Wissenschaftszentrum Berlin (WZB) and CEPR \\ Reichpietschufer 50, 10785 Berlin, Germany \\ E-Mail : Clougherty@wz-berlin.de \\ Tel: +493025491427 \\ Pedro Pita Barros \\ Universidade Nova de Lisboa and CEPR \\ FEUNL, Campus de Campolide \\ 1099-032, Lisboa, Portugal \\ E-Mail: PPBarros@fe.unl.pt \\ Tel: +351 213801600
}

February 15, 2007

\begin{abstract}
Antitrust policy involves not just the regulation of anti-competitive behavior, but also an important deterrence effect. Neither scholars nor policymakers have fully researched the deterrence effects of merger policy tools, as they have been unable to empirically measure these effects. We consider the ability of different antitrust actions - Prohibitions, Remedies, and Monitorings - to deter firms from engaging in mergers. We employ crossjurisdiction/pan-time data on merger policy to empirically estimate the impact of antitrust actions on future merger frequencies. We find merger prohibitions to lead to decreased merger notifications in subsequent periods, and remedies to weakly increase future merger notifications: in other words, prohibitions involve a deterrence effect but remedies do not.
\end{abstract}

JEL: L40, L49, K21

* Corresponding author. We wish to thank Jan De Loecker, Robert Feinberg, Michal Grajek, and LarsHendrik Röller, and especially Tomaso Duso for helpful discussions; participants at the ASSET conference in Lisbon, City University London, CEPR Applied IO workshop in Madeira, CPIM-CEPR workshop in Brussels, DIW in Berlin, IIOC conference in Boston, SFB seminar in Mannheim, Spanish IO workshop in Barcelona, Trinity College Dublin, University of Paris Pantheon-Sorbonne, and IUI in Stockholm for helpful comments; Claudia Alves and Enno Schroeder for excellent research assistance. Jo Seldeslachts recognizes financial assistance from the EC $5^{\text {th }}$ framework program: RTN (HPRN-CT2002-00224). 


\section{INTRODUCTION}

Antitrust policy involves more than just the policing of actual antitrust cases and violations; it also involves deterrence effects. Paul Joskow states "U.S. antitrust policy is primarily a 'deterrence' system not a regulatory system" (2002: 98). Antitrust policy simply cannot scrutinize and vet all market behaviors, but instead relies on the development of antitrust rules which businesses are expected to internalize into their decisions. That deterrence effect is best enabled by an antitrust law system with clear signals and repercussions. For instance, Owen (2003) points out how the lack of resources and the inability to create credible commitments has led to the absence of any deterrence effect for Latin American antitrust policies; while Stigler (1966) attributes the decline in the relative frequency of horizontal mergers in the 1950's to the deterrence effects of more vigorous enforcement of US antitrust laws. Accordingly, antitrust actions - when entwined with effective deterrence - may involve robust policy implications. ${ }^{1}$ In essence, the number of actual cases involving antitrust actions is potentially just the 'tip of the iceberg' when it comes to merger policy effects, as additional anti-competitive mergers are considered by businesses but never proposed (Davies \& Majumdar, 2002).

While an important issue, research on the deterrence effects of antitrust policy is generally an underdeveloped area. The 'dearth of literature' charge holds less well for collusion and anti-cartel policies where a number of studies exist (Block, Nold \& Sidak, 1981; Kobayashi, 2002; Spagnolo, 2007). Merger policy, however, is an area where deterrence has been particularly under-researched. For instance, the influential U.S. Federal Trade Commission (1999) divestiture study does not factor deterrence implications. Instead, the authors simply acknowledge that the total effect of the Commission's merger enforcement is presumably much greater than reflected by the actual number of remedies and prohibitions;

\footnotetext{
${ }^{1}$ By antitrust actions, we collectively refer to the use of various merger policy tools by antitrust authorities: monitored mergers, remedied mergers, and merger prohibitions - all constitute antitrust actions (see 'The Data' section for more explanation).
} 
hence, they observe that deterred merger undertakings must certainly exist. This lack of accounting for merger-policy deterrence effects is also exhibited by the U.S. Department of Justice (DOJ) which stated in its Fiscal Year 2001 Congressional submission: "we have not attempted to value the deterrent effects ... of our successful enforcement efforts. While we believe that these effects ... are very large, we are unable to approach measuring them” [Davies \& Majumdar, 2002: p. 72]. A number of scholars (Eckbo, 1989; Davies \& Majumdar, 2002; Joskow, 2002; Crandall \& Winston, 2003; Baker, 2003) agree that the lack of accounting for deterrence-effects suggests that the total-effect of merger policy is far more consequential than we currently acknowledge.

Antitrust authorities in recent years have shown a proclivity to employ remedies to ameliorate the anti-competitive elements of proposed mergers instead of engaging in out-andout prohibitions. For instance, the European Commission (EC) has largely relied on structural and behavioral remedies by only blocking one merger since 2001. In the US, remedies constituted only twenty-three percent of US merger policy actions in the late 1980s; but by the year 2000, remedies were employed in over sixty percent of US merger cases requiring antitrust action (Parker \& Balto, 2000). The increased adoption of remedies spurred the U.S. Federal Trade Commission (FTC) into studying the success of divestitures as a remedy for anti-competitive concerns: that already-mentioned study (U.S. FTC, 1999) found divestitures to generally create viable competitors. ${ }^{2}$ Accordingly, the FTC issued guidelines for remedies in 1999, the EC followed suit by issuing guidelines in 2001, and the U.S. Department of Justice (DOJ) in 2004 (Duso, Gugler \& Yurtoglu, 2007). The codification of remedies as an important merger policy tool in these three highly visible authorities would seemingly influence less-experienced authorities which look to established authorities for guidance and benchmarking in the development of antitrust practices. An example of an overt influence by established authorities on less-experienced authorities rests with the European Union's (EU)

\footnotetext{
${ }^{2}$ See Duso, Gugler \& Yurtoglu (2006, 2007) for a more sobering assessment of the success of EU remedies.
} 
accession criteria mandating that candidate-nation antitrust policies conform to EU policies (Dutz \& Vagliasindi, 2000). Figure 1 corroborates the above conjecture on the diffusion of remedies as a favored practice by illustrating that the average ratio of remedies to prohibitions has substantially increased over the 1995-2005 period; thus, remedies have become by-far the most popular merger-policy tool in the cross-national environment for antitrust.

Our main concern is that the above three points - i., the fact that merger policy involves important deterrence implications; ii., the deterrence effects of merger policy have, however, largely gone unmeasured; iii., the trend towards increased use of remedies as opposed to prohibitions as a merger policy tool - raise a potentially important issue that may have been neglected by antitrust authorities. In particular, the increased adoption of remedies as a tool to ameliorate the anti-competitive concerns with proposed mergers may come at the opportunity cost of neglecting the proper deterrence role of merger policy. Remedies may deal with the immediate anti-competitive concerns due to a proposed transaction, but may not send the necessary clear-signal of 'probable detection and serious consequences' for effective deterrence. In short, for deterrence purposes merger remedies may be an ineffective policy instrument; hence, the trend toward increased deployment of remedies as a merger policy tool may come at the expense of decreased deterrence.

Accordingly, we propose to study here the impact of different merger policy tools (prohibitions, remedies and monitorings) on the proclivity of firms to engage in future merger transactions. After all, antitrust policy is directly aimed at firms' conduct; hence, considering the effect of changes in merger policy on firms' future merger behavior merits attention. The immediate benefits of such a study are twofold. First, we begin the process of factoring the deterrence-effects of merger policy; thus, we start to quantify what has until now been unquantified. Second, by considering the deterrence-effects of different merger policy tools we are able to elicit which particular tools involve adequate deterrence. As Crandall and Winston argue, a need exists to "explain why some enforcement actions and remedies are 
helpful and others are not” (2003: 4). We begin that exercise of detecting the effectiveness of different merger policy instruments by considering whether prohibitions, remedies, and monitorings act as effective deterrents with regard to future merger frequencies.

In order to support our analysis, the structure of the paper is as follows. Section II reviews the relevant existing literature in order to properly frame our contribution. Section III formally generates empirical expectations by setting out a model where prohibitions and remedies represent costs to proposed merger transactions; thus, spikes in antitrust actions potentially result in frequency-based deterrence. Section IV describes the unique crosssection/time-series data set (28 antitrust jurisdictions over the 1992-2005 period) employed for the empirical estimations. Section V describes the issues and techniques with regard to our dynamic panel data estimation. Section VI presents the empirical results. Section VII discusses and concludes.

\section{BACKGROUND ON RELATED LITERATURE}

A number of studies mention the importance of deterrence with respect to merger policy (Joskow, 2002; Crandall \& Winston, 2003; Baker, 2003); however, very few studies with the exception of Davies and Majumdar's (2002) commissioned report for the UK Office of Fair Trading (OFT) - go further to analyze in depth the deterrence effects involved with merger policy. Instead, the great majority of the substantive scholarship on antitrust deterrence focuses on anti-cartel and collusion policies: in other words, what are the proper penalties to discourage collusion. Nevertheless, two general strands of empirical literature exist that broadly consider the merger-policy/deterrence-effect relationship: first, a few studies consider the composition of mergers to elicit how merger policy law changes might alter the nature of proposed mergers; second, a series of studies employ price-cost margins to measure the net-impact of antitrust and merger policies. The following paragraphs quickly review the above three literature strands (cartel deterrence, composition-based deterrence, and 
price-cost markup studies) in order to further motivate our analysis and nest our contribution in the relevant literature.

First, the most extensive literature on antitrust deterrence resides in the realm of anticartel and collusion policies. Building on Becker's (1968) and Ehrlich’s (1973) early work on the economics of illicit behavior, a great deal of scholarship has considered how collusivepricing and market-sharing behavior might be understood, detected, and discouraged (see Baker, 2001; Van Eden, 2002; Spagnolo, 2007 for reviews). The following works in this tradition appear most germane to our topic, as they empirically support the existence of a deterrence effect when it comes to anti-cartel and collusion policy. Feinberg (1980) finds firms incurring Sherman act enforcements to subsequently have lower markups. Block, Nold and Sidak (1981) observe cartel prosecutions in one market to decrease markups in both that market and in similar regional markets. Block and Feinstein (1986) find antitrust enforcement in one market to robustly spillover into other sub-markets. Furthermore, Clarke and Evenett (2003) show that international cartel members tend to reduce their overcharges in national jurisdictions with strong cartel enforcement regimes. Accordingly, the empirical literature appears to have substantiated the existence of deterrence effects for anti-cartel policy.

Second, a small literature exists on the deterrence effects of merger policy with respect to the composition of proposed mergers. As Aaronson (1992) notes, merger policy deterrence effects conceivably manifest in merger plans being forsaken (namely, a frequency-based deterrence effect), but also in mergers being shaped differently (namely, a composition-based deterrence effect). George Stigler (1966) first considered composition-based deterrence effects when he considered the impact of the 1950 anti-merger amendment to the Clayton Act. He found that statute - and the enforcement of that statute - to substantially discourage the proposal of horizontal mergers and encourage the proposal of vertical and conglomerate mergers; hence, the composition of mergers tilted toward more vertical and conglomerate 
types of pairings. ${ }^{3}$ Following in this vein, B. Espen Eckbo employed stock-price data to measure the composition of mergers and gain insights in to both merger welfare implications and potential deterrence effects. ${ }^{4}$ Eckbo and Wier (1985) present evidence that non-merging firms (rivals to the merger) generally earned higher stock market premiums prior to the onset of the U.S. Hart-Scott-Rodino (HSR) reform than they did post-HSR; thus, suggesting that the HSR act deterred a number of anti-competitive mergers. ${ }^{5}$ Note, however, that Eckbo and Wier go on to question the optimality of the HSR act as they find antitrust actions to generally be anti-competitive: in that, rival firms surprisingly experience positive abnormal returns when authorities take action against merger proposals. Eckbo (1989) attempts to clarify the above contribution when he agrees that mergers are certainly deterred by more aggressive antitrust policy; though, he is concerned that efficient mergers are generally being deterred. In later work, Eckbo (1992) makes use of the absence of Canadian antitrust enforcement prior to 1985 to indirectly test whether US policy deters anti-competitive mergers. He conjectures that there should be more anti-competitive horizontal mergers in Canada due to effective US deterrence; yet over the 1961-1982 period, he finds no evidence of the composition of proposed Canadian mergers being more anti-competitive than the composition of proposed US mergers. Although Eckbo (1992) considers how merger policy influences the type of proposed mergers (at least with respect to stock market evaluation), he does not directly identify whether a change in policy impacts (namely, deters) future merger behavior.

\footnotetext{
${ }^{3}$ In response to tougher antitrust policy, firms can also try to change antitrust authority behavior. Pittman (1977), for example, finds that US firms increase their political campaign contributions in the years subsequent to receiving heavy antitrust scrutiny.

${ }^{4}$ B. Espen Eckbo (1983) and Robert Stillman (1983) first employed the event-study method on stock-price data to measure the welfare implications of mergers. The event study methodology measures the impact of an event on financial markets. In the merger policy context, the method concentrates on how a merger changes the market value of outsiders (rivals). A positive (negative) abnormal return to outsiders suggests a market-power enhancing (efficiency-gains increasing) merger, as the merger improves (reduces) the competitive position of rivals. The methodology has also received recent attention by scholars analyzing merger policy: for example, Duso, Neven \& Röller, 2007; Duso, Gugler \& Yurtoglu, 2006, 2007; Fridolfsson \& Stennek, 2005.

${ }^{5}$ See Werden and Williams (1989) for a pointed critique of Eckbo \& Wier (1985) and a good critique of the event-study methods' appropriateness for evaluating merger policy (Fridolfsson \& Stennek, 2005 also perform the latter).
} 
Third, a number of studies look at how antitrust policy indirectly influences firm behavior by studying its impact on industries 'market power and price-cost margins'. This literature, however, tends to be somewhat inconclusive as some studies generate evidence critical of antitrust policy while others generate supportive evidence. The critical studies include: Crandall and Winston’s (2003) finding unsuccessful merger challenges to decrease and consent-decrees (divestitures) to increase price-cost margins in US manufacturing industries; Konings, Van Cayseele and Warzinsky (2001) detecting no significant changes in Belgian firms’ mark-ups after the strengthening of Belgian antitrust laws in 1993, but lower price mark-ups in the Netherlands where there was then no effective antitrust policy. The supportive studies include: Block, Nold and Sidak’s (1981) finding larger antitrust budgets to decrease markups for bread in the US; Warzinsky (2001) detecting tougher US merger policy from 1945-1973 leading to lower firm mark-ups as compared to the more lax period of 19731991; Hoekman and Kee’s (2003) forty-two country study where the presence of antitrust legislation generates lower mark-ups via improved entry conditions. The above studies conceivably capture both the direct regulatory effects and the indirect deterrence effects involved with the establishment, resourcing and use of antitrust policies, but, do not disentangle the regulatory from the deterrence effects.

The literature summarized above covers a great deal of ground and generates a number of important insights, but suffers from some limitations. First, most of the above studies in the merger policy realm use only one observation of policy change: the before versus after a policy change comparison (Stigler, 1966; Eckbo \& Wier, 1985; Konings, Van Cayseele and Warzinsky 2001; Warzinsky, 2001; Hoekman and Kee, 2003), or the countrieshaving versus countries-not-having antitrust laws comparison (Eckbo, 1992; Konings, Van Cayseele and Warzinsky, 2001). Second, the price-cost markup literature finds it difficult - as already noted - to disentangle regulatory from deterrence effects: in essence, markups capture the 'total effect' of antitrust policies. Furthermore, by only looking at resulting market 
outcomes, the markup studies fail to consider merger behavior directly and fail to capture direct responses by firms to changing antitrust policies. Third, the existence of empirical studies considering the composition-based deterrence effects is important; however, there does not appear to be a companion literature that analyzes frequency-based deterrence effects - an equally important manifestation of deterrence. Fourth, it is fair to say that the empirical literature on the deterrence effects of cartel policy is far more advanced (and consistently supportive) than the literature concerning the deterrence effects of merger policy.

We propose then to directly analyze the deterrence effects of different merger policy tools on future merger behavior, and by doing so, we hope to improve upon the existing literature in some respects. First, by considering the annual use of merger policy tools by different antitrust jurisdictions, we have numerous antitrust actions that provide multiple observations of antitrust conduct and help us move beyond the previous before/after and having/not-having comparisons. Second, by considering future changes in the number of notified mergers, we are both able to capture the proclivity to seek mergers (actual merger behavior) and to separate out the deterrence effects of merger policy from the regulatory effects. Third, by fixing the number of notified mergers as the dependent variable of interest, we are also able to provide some evidence with respect to the frequency-based deterrence effects of merger policy (namely, how many mergers are forsaken) as opposed to the literature's (admittedly a small literature) focus on the composition of proposed mergers. Fourth, we provide a much needed approach to advance the literature on measuring the deterrence effects of merger policy. As already noted, antitrust authorities and scholars have been at an impasse as to how to proceed and measure merger-policy deterrence effects.

We should be clear here and note that investigating a change in the number of notified mergers does not necessarily equate to a change in the number of anti-competitive mergersthe main interest of antitrust authorities. Eckbo $(1989,1992)$ has made this point in expressing concern, backed by some evidence, as to socially-efficient mergers being the types that are 
primarily deterred. It seems, however, more probable that a change in antitrust actions would have a greater impact on potential anti-competitive mergers than on potential competitive mergers. However in our data, we are unable to detect whether deterred mergers are efficient or anti-competitive; instead, we can only elicit frequency-based and not composition-based deterrence. Nevertheless, frequency-based deterrence is important once one realizes that antitrust authorities generally lack the resources and manpower to sufficiently vet all of the problematic merger proposals. Furthermore, the following theoretical section will show that in our model frequency-based deterrence involves less ambiguous empirical predictions than does composition-based deterrence.

\section{DETERRENCE EFFECTS}

In order to ground the empirical analysis, it behooves us to analyze in a somewhat formal manner how merger policy tools may involve deterrence effects. An attempt to think rigorously about the effects of different merger policy instruments helps us move beyond casual justifications for empirical expectations. We concentrate here on the frequency-based deterrence effects of both prohibitions and remedies; furthermore, we consider the implications of a shift in the use of one policy tool (for example, prohibitions) towards another policy tool (for example, remedies), and how that may affect future merger frequencies. The premise behind our theoretical foundations is that spikes in remedies and prohibitions signal to firms the future intentions and tendencies of antitrust authorities.

We know that effective deterrence for antitrust policy requires those potentially tempted by anti-competitive actions to have a degree of certainty regarding the rules, and to believe that transgressing those rules involves a reasonable probability of being caught and suffering serious consequences (Craswell \& Calfee, 1986; Baker, 2001). Becker (1968) notes that if the aim is simple deterrence then raising the probability of conviction close to one and having punishments exceed the gains of the crime would virtually eliminate offences. That 
insight simply suggests that effective deterrence requires the probability of detection and fines to be sufficiently high.

To begin conceptualizing how deterrence effects can be operationalized in a merger context, we first consider the makeup of merger-related profits. While some mergers certainly create general efficiencies, Werden and Williams (1989) remark that mergers can have different effects in different markets. ${ }^{6}$ In other words, overall efficiency-effects might be produced in some markets while anti-competitive effects dominate in other markets. Davies and Majumdar (2002) point out that multi-product mergers between firms enhance this varied effects phenomenon. Accordingly, we can split merging firms’ profit gains into procompetitive profits $\left(\Pi^{\mathrm{PC}}\right)$ that do not harm social welfare, and anti-competitive profits $\left(\Pi^{\mathrm{AC}}\right)$ that come at the expense of social welfare- $\Pi^{\mathrm{AC}}$ represents the extra profits for merging firms when they cross the boundaries of merger policy regulations. Total merger profits equal then the sum of profits from markets where firms’ efficiency gains dominate and from markets where the anti-competitive elements dominate-total merger profits are thus $\Pi^{\mathrm{AC}}+\Pi^{\mathrm{PC}}$.

Let us now think about the differences between the two antitrust actions of prohibitions and remedies. ${ }^{7}$ In the case of a prohibition, the penalty for proposing a merger with significant anti-competitive problems involves the full prohibition of the merger: both the pro-competitive and the anti-competitive profits for merging firms are negated by the prohibition. The throwing out of the pro-competitive profits along with the anti-competitive profits is important, as this brings about the punitive measure that Posner (1970) acknowledges as being crucial for deterrence. The big difference between remedies and prohibitions is that remedies attempt to identify and eliminate the anti-competitive elements of a merger. In essence, the merging firms are able to hold on to the pro-competitive elements of the merger-so they keep ( $\left.\Pi^{\mathrm{PC}}\right)$, but the anti-competitive elements of the merger $\left(\Pi^{\mathrm{AC}}\right)$ are

\footnotetext{
${ }^{6}$ See Röller, Stennek and Verboven (2000) for a survey of horizontal mergers and efficiency gains.

${ }^{7}$ These are the main decisions antitrust authorities take nowadays.
} 
negated by the remedial action. If an antitrust authority imposes remedies, then the disincentive for firms to propose anti-competitive mergers is clearly lower. In short, prohibitions seemingly involve more deterrence than do remedies, as prohibitions represent larger punishments.

With the above as a backdrop, we now give a more formal structure and introduce some additional features to make our analysis realistic and suited for our empirical testing. The features of our model include the following: firms decide on the type - namely, restrictiveness - of mergers proposed; antitrust authorities either clear, remedy or prohibit a merger proposal; an antitrust authority has the option to alter the tendencies of its merger policy regime (for example, using more remedies at the expense of prohibitions); and uncertainty exists regarding an antitrust authority’s stance. ${ }^{8}$

First, the nature of the proposed merger will clearly affect merger profitability; in particular, the restrictiveness level $(\eta)$ of a merger proposal will influence both the procompetitive and anti-competitive elements of merger profitability. For instance, firms may take merger measures that simultaneously increase both efficiency (yielding pro-competitive profits) and market power (yielding anti-competitive profits): the closing of branches in the case of bank mergers might generate efficiencies but also soften price competition. Accordingly, we define restrictiveness broadly: decisions over merger targets, product lines, geographic markets, contracts with suppliers, and so on-are all subsumed in this variable $\eta$. Naturally, the level of anti-competitive profits depends positively on the degree of restrictiveness for the proposed merger, $\frac{\partial \Pi^{A C}(\eta)}{\partial \eta} \geq 0$. For instance, a firm may decide to acquire a direct competitor in lieu of a less-related target, thus increasing restrictiveness and thereby anti-competitive profits.

\footnotetext{
${ }^{8}$ Sah (1991) models a process similar to our setup, but in the context of explaining patterns of crime. As we do, he is interested in investigating how individuals' choices are determined endogenously, while incorporating the information available to them. The resulting dynamic relationships are then studied to examine how behaviour might evolve over time.
} 
The restrictiveness-level decision should in general positively impact a merger's procompetitive profits $\left(\Pi^{P C}(\eta)\right)$, as any efficiency effects from greater restrictiveness will translate into increased pro-competitive profits. For instance, more market power may lead to a higher innovation incentive, thus leading to more efficiency-efficiency effects which may dominate market-power effects in some markets but not in other markets. While the impact of restrictiveness on pro-competitive profits may in principle be negative at times, the impact of restrictiveness on anti-competitive profits dwarfs the impact on pro-competitive profits. Hence, the net effect of restrictiveness on total profits $\left(\Pi^{\mathrm{AC}}+\Pi^{\mathrm{PC}}\right)$ is very likely to be positive, as firms choose $\eta$ in such a way as to maximise total profits. Thus, it is intuitive to follow Barros (2003) and assume that total profits increase: $\frac{\partial \Pi^{A C}(\eta)}{\partial \eta}+\frac{\partial \Pi^{P C}(\eta)}{\partial \eta} \geq 0$. In short, firms have a profit incentive to propose mergers with higher levels of restrictiveness.

The antitrust authority then assesses the merger by confronting the restrictiveness level, $\eta$, proposed by the merging firms with its own judgement of the market-a judgement that defines an admissible level $\hat{\eta}$. As already noted, antitrust authorities - when facing a merger - have three possible decisions: prohibit the merger, remedy the merger to allow for approval, and clear the merger without conditions. We model this decision process in a simple way: for $\eta \leq \hat{\eta}$, the merger is cleared without any conditions; for $\hat{\eta}<\eta \leq \hat{\eta}+\alpha$, the merger is subjected to remedies. Note that parameter $\alpha$ - the range for the remedy solution - denotes the extra level of restrictiveness the authority is willing to accept as long as remedies are imposed. Finally, for $\eta>\hat{\eta}+\alpha$, the merger is not allowed under any conditions-the merger is prohibited.

The judgement of the antitrust authority with respect to admissible levels of restrictiveness is ex-ante unclear to firms when they decide on whether to propose a merger and on which type of merger to propose. Unlike cartels - where it is relatively easy for firms to see where the lines are drawn - many merging firms will be uncertain as to whether a 
proposed merger would be too restrictive in the eyes of the antitrust authority. Merger policy regulations exhibit a degree of uncertainty as antitrust authorities can give guidelines but not very precise guidelines (Davies \& Majumdar, 2002)—in essence, merger policy is simply too complex to generate 'per se' rules. Accordingly, a key ingredient for a firm’s choice of merger is the expected $\hat{\eta}$. The expectation about the critical restrictiveness value, $\hat{\eta}$, is represented by the probability distribution $F(\hat{\eta}){ }^{9}$

According to the above setup (where the merging parties receive the full profits under a clearance, the pro-competitive profits under a remedy, and no profits under a prohibition), firms expect a profit given by:

$$
V=\left(\Pi^{A C}(\eta)+\Pi^{P C}(\eta)\right)(1-F(\eta))+(F(\eta)-F(\eta-\alpha)) \Pi^{P C}(\eta)-K
$$

Note that $K$ measures the cost of building up the merger proposal-a fixed cost. Accordingly, a merger is proposed if firms, after choosing optimally $\eta$ (namely, maximize $V$ with respect to $\eta$ ), have $V>0$. Clearly, a lower $K$ leads to more mergers. Yet more interesting is the impact of a change in $\alpha$, as this reflects a merger policy change (a movement of the boundary between remedies and prohibitions). Increasing $\alpha$ means that authorities are willing to use remedies in cases where previously they would outright reject a merger. Per our descriptive analysis, this policy substitution from prohibitions to remedies is empirically relevant.

By the envelope theorem, the impact on merger proposals can be seen from

$$
\frac{\partial V}{\partial \alpha}=f(\eta-\alpha) \Pi^{P C}(\eta)>0
$$

Hence, the policy substitution from prohibitions to remedies should induce a higher number of future merger proposals. Curiously, the effect upon the restrictiveness of future merger proposals - namely, $(\partial \eta / \partial \alpha)$ - is ambiguous. Indeed, via an application of the envelope theorem, $\operatorname{sign}(\partial \eta / \partial \alpha)=\operatorname{sign}\left(\partial^{2} V / \partial \eta \partial \alpha\right)$; and taking the derivative yields

\footnotetext{
${ }^{9}$ To simplify the exposition we take $\alpha$ to be known, but explain below how it would work with uncertainty over $\alpha$.
} 


$$
\frac{\partial^{2} V}{\partial \eta \partial \alpha}=\frac{\partial f(\eta-\alpha)}{\partial(\eta-\alpha)} \Pi^{P C}(\eta)+f(\eta-\alpha) \frac{\partial \Pi^{P c}(\eta)}{\partial \eta} .
$$

Importantly, both the first and second terms can be negative: replacing prohibitions with remedies could lead to less - not more - restrictiveness in future merger proposals. The first term can be either positive or negative, depending on the distribution shape of $f($.$) in the range$ of $\eta-\alpha \cdot{ }^{10,11}$ The first terms indeterminate sign owes to the change in alpha involving two different effects. By increasing $\alpha$, the antitrust authority applies remedies to some mergers that previously incurred prohibitions; thus, merging firms are more likely to obtain the procompetitive profits. When pro-competitive profits are positively correlated with restrictiveness, the marginal benefit from a higher $\eta$ increases. The importance of this extra incentive to increasing $\eta$, however, depends on how often firms expect to be in this range: in general, the number of cases to which this applies is likely to be smaller for a higher $\eta$. When the marginal impact of restrictiveness on pro-competitive profits is small and increasing $\eta$ increases the probability of incurring a prohibition then the firms involved in the merger may prefer to reduce restrictiveness in order to increase the probability that the merger incurs a remedy as opposed to a prohibition. Furthermore, the second term can also be negative when a more restrictive merger yields lower pro-competitive profits. In short, our model generates ambiguous predictions with regard to the composition of future merger proposals; in other words, the equilibrium effect on composition-based deterrence is not clear. The predictions on the frequency of future merger proposals - namely, frequency-based deterrence - suggest a more unambiguous effect; accordingly, the number of mergers represents our natural variable of interest when it comes to measuring deterrence effects.

The same model can be used to address two additional policy shifts of importance: increasing remedies at the expense of fewer clearances; and increasing prohibitions at the

\footnotetext{
${ }^{10}$ If we take, for example, $F$ to be a negative exponential density, the effect would be negative. On the other hand, if $\mathrm{F}$ is a density with an increasing hazard rate (for example, the normal or weibull distributions), then the effect would be positive.
} 
expense of fewer clearances. The simplest way to look at these "policy shifts" is to see them as transfers of mass probability from one region of the probability distribution $F$ to anothera simplification that allows us to clearly convey the basic intuition. Take the following definition of expected profit from a notified merger:

$$
V=\left(\Pi^{P C}+\Pi^{A C}\right)\left(1-F(\eta)-\beta_{1}-\beta_{2}\right)+\Pi^{P C}\left(F(\eta)-F(\eta-\alpha)+\beta_{1}\right)-K
$$

where $\beta_{1}$ is a mass probability increase for remedies imposition coming at the expense of a lowering in clearances, while $\beta_{2}$ is the increase in mass probability for prohibitions coming at the expense of clearances. Using again the envelope theorem, we see that the number of notified mergers drops as $\beta_{i}$ increases; but moreover, the restrictiveness of the proposed mergers does not necessarily decrease. ${ }^{12}$ From this simple model, we can extract some implications regarding policy shifts that can be summarized in the following table:

\begin{tabular}{lll} 
Policy Change & Notifications & Restrictiveness \\
\hline $\begin{array}{l}\text { Increase in } \\
\text { prohibitions with a } \\
\text { decrease in clearances }\end{array}$ & Decrease & Uncertain \\
\hline $\begin{array}{l}\text { Increase in } \\
\text { prohibitions with a } \\
\text { decrease in remedies }\end{array}$ & Decrease & Uncertain \\
\hline $\begin{array}{l}\text { Increase in remedies } \\
\text { with a decrease in } \\
\text { clearances }\end{array}$ & Decrease & Uncertain \\
\hline
\end{tabular}

Before turning to empirical expectations, it is important to conceptually make the link between changes in merger policy, changes in antitrust actions, and changes in firm beliefs with regard to antitrust stances. We propose here how one might reason the above process while taking into account uncertainty regarding merger policy rules. First off - due to the lack of clarity for merger policy rules - firms must make inferences as to the actual stances of antitrust authorities: namely, what are the critical parameters for eliciting remedies and prohibitions. Firms make inferences then about $\hat{\eta}$ and $\alpha$ based both on the antitrust

\footnotetext{
${ }^{12}$ Verifying these claims amounts to simple comparative statics exercises on $\eta$.
} 
authorities' past antitrust actions and on the imperfect knowledge firms have of the $\eta$ for the previously proposed mergers of other firms. ${ }^{13}$ The imperfect knowledge comes from information publicly released - from the press and antitrust authorities - about the merger and from information firms have about the industry. ${ }^{14}$ Changes in antitrust actions (prohibitions and remedies) represent then manifestations of actual merger policy changes; hence, firms update their beliefs on the antitrust authority's stance when they witness changes in antitrust actions. If this updating is done in a Bayesian manner, then increases in a particular antitrust action lead to the positive updating of the probability of eliciting such an action. Indeed, Sah (1991) showed that if perceptions are described by Bayesian inference, then the above properties are satisfied. Accordingly, a spike in the application of a particular antitrust action can lead to firms updating their perception about an antitrust authority's real position; in other words, a change in antitrust actions potentially signals the future tenor of merger policy. ${ }^{15}$ With the above in mind, we can generate some simple expectations for empirical testing.

First, we predict that a spike in prohibitions leads to positive updating of the perceived probability of a prohibition. Prohibition spikes may reflect that the boundary between remedies and prohibitions has been altered (a decrease in the perceived $\alpha$ ), but may also reflect a mass transfer in probability from clearances to prohibitions. Since prohibitions have a significant deterrence effect (namely, they represent a higher cost to merging as compared to remedies and clearances), individual firms will be less inclined to propose a merger and future merger notifications should go down. The above can be summarized as follows:

\footnotetext{
${ }^{13}$ This would work similarly for $\beta_{1}$ and $\beta_{2}$. Recall that the certainty assumption in the formal model with regard to merger policy rule ' $\alpha$ ' (and for $\beta_{1}$ and $\beta_{2}$ ) was done for tractability reasons.

${ }^{14}$ If other firms, for example, propose a merger that would create a monopoly or facilitate exclusive territories; then, the proposed $\eta$ is high. If the proposed merger would not substantially increase concentration; then, the proposed $\eta$ is low. Authorities decide then on a particular antitrust action for each proposed merger with its attendant restrictiveness level. Accordingly, firms 'see' $\hat{\eta}$ and $\alpha$ through previous merger proposals and the antitrust actions taken in these cases.

${ }^{15}$ Take for instance an increase in prohibitions: if a merger with high $\eta$ is rejected, then there may be little updating on $\alpha$. If, on the other hand, firms see a prohibition of a merger with a relatively low $\eta$, then $\alpha$ is revised substantially downwards.
} 
Hypothesis 1: An increase in prohibitions leads to frequency-based deterrence: a decrease in future merger notifications.

Second, we predict that a spike in remedies leads to positive updating of the perceived probability of a remedy. Remedy spikes may reflect that the boundary between remedies and prohibitions has been altered (an increase in the perceived $\alpha$ ), but may also reflect a mass transfer in probability from clearances to remedies. Accordingly, an increase in remedies may have two possible effects on future merger frequencies: 1) a negative effect when remedies come at the expense of clearances; 2) a positive effect when remedies come at the expense of prohibitions. Thus when firms positively update their perceptions about an authority using remedies, the net-effect depends on whether the spike in remedies lowers the perceived probability of prohibitions more than the perceived probability of clearances. If the former effect dominates, then an increase in remedies leads to the perception of a less-tough future merger policy and we should witness a higher proclivity for firms to seek mergers. On the other hand, if the probabilities of future clearances go down then an increase in remedies should result in a lower proclivity for firms to seek mergers. The above can be summarized as follows:

Hypothesis 2: An increase in remedies leads to indeterminate frequency-based deterrence: future merger notifications decrease when remedies substitute for clearances, but future merger notifications increase when remedies substitute for prohibitions.

To keep things simple, we have until this point excluded the merger policy option of monitorings. In part, this was driven by the prior that the effects of monitorings are relatively suspect, as firms subjected to monitorings may not actually be incurring a real punishment. Monitorings may then send a noisy signal of an antitrust authority's true intentions; hence, merging parties perceptions may not change. In fact, nowhere have we seen any claims by 
antitrust authorities or experts that monitorings involve deterrence. Nevertheless, we will consider the impact of monitorings - since they are an antitrust action - on future merger frequencies in the empirical setup.

\section{THE DATA}

The actual data consist of annual measures of merger policy for 28 antitrust jurisdictions over the 1992-2005 period; hence, the unit of observation for the empirical tests is antitrust jurisdiction by year. The OECD directs members and associates to respond to specific questions in order to generate annual reports on the state of antitrust policy in those jurisdictions. Thus, the OECD's annual reports on 'Competition Policy in OECD Countries' provide raw data on cross-national antitrust policies that can be compiled into empirical measures. While the OECD reports are the main source of data for this study, additional data were gathered via direct contact with—and specific reports from—actual antitrust authorities in order to fill any data holes and reconcile any incompatibilities. The overriding concern in data compilation was to create consistently accurate measures of national antitrust policies. In doing so, the data are necessarily characterized as unbalanced panels-as a number of annual observations were missing or necessarily dropped in order to yield consistent crossjurisdiction/pan-time measures.

The first construct of primary interest for our empirical analysis is merger behaviornamely, the number of mergers occurring. As a measure for the number of mergers, our dependent variable, we use the annual number of transactions that are notified in the antitrust jurisdiction (hereafter referred to as Mergers). This measure has two main advantages. First, it is a construct with very little measurement error, since antitrust authorities report accurately the number of notified mergers by year. Second, it is probable that those mergers that must be notified to merger authorities_-of which the number of potentially anti-competitive mergers is 
a subset-are the ones that change their behavior the most in response to a change in antitrust actions.

We also have measures that help capture the annual level of regulatory scrutiny given merger activity in a particular antitrust jurisdiction: our core explanatory variables. 'Antitrust Actions' refers to an antitrust jurisdictions annual sum of monitorings, remedies, and prohibitions. Where 'Monitorings' are the number of transactions cleared but with commitments by the antitrust authority to monitor post-merger behavior, 'Remedies' are the number of transactions cleared but forced to undertake behavioral or structural remedies to ameliorate anti-competitive concerns, and 'Prohibitions' are the number of transactions that are out-right prevented by the antitrust authority. ${ }^{16}$ Accordingly, antitrust actions represent an annual count of the possible merger policy actions taken by a particular jurisdiction with respect to merger behavior: with monitorings, remedies and prohibitions representing the three sub-categories of actions. Table 1 reports summary statistics - based on the observations employed in the empirical estimations - for the Mergers variable and the three types of Antitrust Actions broken down by the twenty-eight antitrust jurisdictions.

Antitrust authorities have steadily increased their actions during the 1990's both in absolute and relative terms. With regard to an absolute increase in antitrust actions: the average number of yearly antitrust actions has evolved from a little under six actions per jurisdiction at the beginning of our sample to a peak of roughly 10.4 actions per jurisdiction in 2000. Figure 2 illustrates the trend in yearly antitrust actions along with the average number

\footnotetext{
${ }^{16}$ It should be noted that we have data on Abandonments (number of transactions abandoned by merging parties due to anti-competitive concerns by the antitrust authority) for twenty five jurisdictions (except Australia, Greece and the US). However, this measure of Antitrust Action suffers from a great deal of measurement error, as antitrust authorities differ significantly in the degree to which (and how) they report this measure. Nevertheless, we should state that the empirical results reported later in the paper are very much robust to the inclusion of this additional Antitrust Action variable in unreported estimations (this fact is doubly important once we recognize that the auxiliary estimations exclude the US—a seemingly important antitrust jurisdiction). Furthermore, the coefficient estimates regarding the frequency-based deterrence effect of Abandonments are insignificant.
} 
of merger notifications per jurisdiction over the 1994-2004 period. Witness how the tendencies in antitrust actions coincide with the global merger wave. ${ }^{17}$

With regard to a relative increase in antitrust actions: figure 3 illustrates the average across all jurisdictions in our data set of the number of antitrust actions relative to the number of notified mergers. The figure shows that in the beginning of the nineties around $1.5 \%$ of all notified mergers triggered an action by authorities, and shows a steady rise in this rate to 5\% by 2005. The tendencies in the absolute number of antitrust actions are surely a response to the merger wave of the nineties. If more mergers are notified, then more mergers may be subject to some sort of antitrust scrutiny-a pure statistical effect. The relative increase of actions, however, tells us more. It may convey that antitrust authorities have become tougher and increasingly "punish” proposed mergers. This observation certainly conforms to the received wisdom that antitrust in the cross-national context has experienced both greater adoption and strengthening over the last two decades. It may also indicate that authorities have raised notification threshold levels in an effective manner in order to not waste limited institutional resources on harmless mergers (De Loecker, Konings \& Van Cayseele, 2007). This leads naturally to a higher percentage of antitrust actions, as the population of notified mergers will consist of more anti-competitive mergers. We will control for this possibility in the empirical specification.

In sum, antitrust authorities responding to the need to vet mergers for anti-competitive effects during the unprecedented 1990’s merger wave have tended toward the following practices. First, we witness an increase in the number of antitrust actions: measured both in absolute terms (figure 2) and with respect to merger notifications (figure 3). The trend manifested in figure 3 toward higher levels of antitrust actions per merger notification is potentially driven by beefed-up antitrust policies and/or by changing merger thresholds for

\footnotetext{
${ }^{17}$ The average number of antitrust actions was around 9.2 in 1998, falling to 8.9 in 1999 and rising again to 10.4 in 2000. Further, the average number of merger notifications peaked at 598 in 1998, falling to 399 in 1999 and rising again to 437 in 2000. Thus -- although not peaking in the same year -- antitrust actions and merger notifications go together both up and down.
} 
reporting. Second, we witness an important trend with respect to the employment of merger policy tools: figure 1 illustrates that antitrust authorities principally—and increasingly—rely on remedies for anti-competitive mergers; and less commonly use the practice of prohibitions.

\section{EMPIRICAL ESTIMATION STRATEGY}

Our formal empirical analysis of the deterrence effects of merger policy tools relies on Mergers as the dependent variable and the various antitrust actions (Prohibitions, Remedies and Monitorings respectively) that an authority undertakes as the core explanatory variables. Yet, the number of antitrust actions undertaken is of course a function of the number of notified Mergers. Thus as a first step in attempting to control for the endogeneity of antitrust actions, we use the various lagged antitrust actions as explanatory variables. ${ }^{18}$ Any study on merger behavior should also take into account that mergers often occur in waves (Harford, 2005). This is very much the case for our data: covering the 1992-2005 period and coinciding with the highest merger wave in history (Gugler, Mueller \& Yurtoglu, 2004). To take this wave behavior into account, we include as right-hand side variables lagged terms of Mergers; hence, current merger behavior is partly explained by past merger behavior. We also include year dummies to capture any additional period-specific shocks.

Merger waves also typically coincide with economic booms and high stock markets (Gugler, Mueller \& Yurtoglu, 2004). Accordingly, we add two control variables for economic conditions to help capture merger waves. First, we add economic growth (percentage change in GDP from the previous year)—-hereafter referred to as 'Growth'. Second, for stock market conditions, we add capitalization of listed companies as a percentage of GDP-hereafter referred to as Stock-Market. Note that the addition of Growth and Stock-Market represents

\footnotetext{
${ }^{18}$ One can argue that an antitrust authority that starts an investigation also gives a signal about its toughness. Unfortunately, the OECD reports do not provide extensive data on the number of investigations started; thus, antitrust investigations are not present in this analysis.
} 
two additional means (beyond the lagged Mergers and period-specific effects) to control for merger waves.

We may also need to control for changes in notification thresholds since we use notified mergers as the dependent variable. Merger thresholds tend to be composed of three different elements (worldwide sales, domestic sales, and market shares); furthermore, different antitrust authorities tend to mix-and-match their use of these three elements with some authorities employing all three elements to elicit notifications and others employing only one or two elements. Moreover, these elements can sometimes be based on individual firm measures or on combined merger entity measures. Given the share complexity and variation in the different types of threshold regulations manifested in the cross-national environment for antitrust, we decided to use dummies for threshold changes. All jurisdictions in our sample experienced a maximum of three threshold changes in our sample period 19922005. Twenty-three jurisdictions experienced at least one change, twelve experienced two changes, and one experienced three changes. ${ }^{19}$ Accordingly, we created three dummy variables: 'Threshold1', 'Threshold2' and 'Threshold3' were respectively set to one for the year (and subsequent years) when jurisdictions experience a first, second and third threshold change.

The period 1992-2005 was also a very active law-making period - in large part due to the expected entrance of ten new EU members. As previously noted, some scholarship considers how changes in antitrust laws impact competition (Stigler, 1966; Hoekman \& Kee, 2003); hence, changes in antitrust statutes may also directly impact merger behavior. We constructed dummies for important changes in antitrust laws based on the OECD reports. It is arguably a rather subjective exercise to identify 'important' changes, so we specifically looked for the words 'important', 'substantial' and 'major' in the reports. We found twenty-

\footnotetext{
${ }^{19}$ Data were collected mainly from Global Competition Review yearbooks and complemented with the OECD reports. The remaining countries that experienced 'no changes' in thresholds (Australia, Italy, New Zealand and Norway) officially do not have merger notification threshold levels.
} 
three jurisdictions to have had at least one important legislative change and nine additional jurisdictions to experience a second important legislative change over the period of study. Accordingly, we again created two dummy variables: 'Law1' and 'Law2' were respectively set to one for the year (and subsequent years) when jurisdictions experienced a first and second substantive change to antitrust legislation. Note also that we will control for panel specific effects; thus, helping to control for institutional differences across antitrust jurisdictions.

The European Union also began applying a whole new set of rules in 2004 that created inter alia a new antitrust enforcement system—an enforcement system based on close cooperation between the European Commission and the national antitrust authorities in the framework of the European Competition Network (ECN). The stated aim was for better coordination of enforcement efforts and the promotion of a common competition culture between the EU and its member states. Given its potential impact, we included an additional dummy 'EU 2004 Reform’: set to one in 2004 and 2005 for all EU member jurisdictions.

Summarizing the above, we estimate how Mergers depend on past Mergers, Antitrust Actions and Controls:

$$
\text { Mergers }_{i, t}=\alpha+\sum_{k} \beta_{k} \text { Mergers }_{i, t-k}+\gamma \text { AntitrustActions }_{i, t-1}+\delta \text { Controls }_{i, t}+\omega_{i}+\lambda_{t}+\varepsilon_{i, t} \text {, }
$$
where $i$ indexes the twenty-eight antitrust jurisdictions, $t$ indexes time (year), and $k$ the number of included lags for Mergers. The vector of Antitrust Actions consists of Prohibitions, Remedies and Monitorings - all lagged. Controls represents the vector of control variables: dummies for the first and second important changes in law (Law1 and Law2), the 2004 reform in the EU (EU 2004 Reform), dummies for the first, second and third threshold changes (Threshold1, Threshold2 and Threshold3), and economic and stock market variables (Growth and Stock-Market). Finally, $\omega_{i}$ represents the unobserved jurisdiction-specific effect, $\lambda_{t}$ are the year dummies and $\varepsilon_{i, t}$ the disturbances. 
We log-transform the Mergers and critical Antitrust Actions variables in order to yield some additional estimation advantages. First, log-transforming helps moderate - or cancel out - the significant size differences between the different antitrust jurisdictions by generating elasticities for coefficient estimates. Second, log-transforming also addresses to some extent the count nature of the data for Mergers and Antitrust Actions by making the data more continuous. ${ }^{20}$ Hence, all the variables are in logs for our estimations-except for the dummy variables and the two economic conditions variables. ${ }^{21}$

It also behooves us to employ the methodology of dynamic panel data models (see Bond, 2003, for a solid overview), as we include autoregressive dynamics of the dependent variable (Mergers) on the right-hand side. The serial correlation in the Mergers series implies that a least-squares or within-groups estimation would result in biased and inconsistent estimates. ${ }^{22}$ For this reason, we estimate our expression instrumenting for lagged Mergers - as well as for the antitrust action and control variables - using the system generalized method of moments (System GMM) estimator proposed by Arellano and Bover (1995).

Arellano and Bond (1991) developed a GMM estimator that treats the model as a system of equations - one for each time period. The predetermined and endogenous variables in first differences are instrumented with suitable lags of their own levels. A problem with the

\footnotetext{
${ }^{20}$ To be precise, since many of our antitrust actions variables report zeros, we use the log-transformation after having added a 1 to all the Antitrust Actions and Mergers variables. Employing the absolute number of antitrust actions as variable constructs instead of relative changes in the action portfolios of different antitrust authorities (for example, prohibitions as a percentage of antitrust actions) yields some estimation benefits. First relative changes in the use of antitrust actions may not properly capture the impact of a spike in the use of a particular antitrust action. Consider for example antitrust authority ' $A$ ' that uses prohibitions in $10 \%$ of all antitrust actions, but takes only 10 antitrust actions per year; thus, effectively blocking one merger a year. Antitrust authority 'A' may actually deter less than an antitrust authority ' $\mathrm{B}$ ': which uses prohibitions in only $5 \%$ of antitrust actions, but takes 100 antitrust actions per year; thus, effectively blocking five mergers per year. Second, relative changes in the antitrust action portfolio are also controlled for by our approach via measuring the impact of a change in a particular antitrust action while holding other actions constant. For example, the coefficient estimate for Prohibitions must be understood as indicating the effect of a spike in yearly prohibitions while holding the absolute number of Remedies and Monitorings constant—variable measures that are also likely to increase during merger wave peaks. Accordingly, our explanatory variable constructs for Antitrust Actions capture both absolute and relative changes in that particular concept.

${ }^{21}$ The economic conditions variables are non-count variables and already expressed in percentage terms: percentage change in economic growth, and stock market valuation as a percentage of overall GDP.

${ }^{22}$ The OLS level estimator is inconsistent and biased upwards, since the lagged term of Mergers is positively correlated with the error term. It can also be shown that the standard Within Group estimator is inconsistent and biased downwards when including autoregressive dynamics of the dependent variable.
} 
original Arellano-Bond estimator is that lagged levels are often poor instruments for first differences. Adding an equation in levels to be estimated with the equation in first differences (namely, estimating a system of equations) improves the performance of the estimator. Arellano and Bover (1995) described how - if the original equations in levels were added to the system - additional moment conditions could be brought to bear to increase efficiency and to reduce finite sample bias. Two testable assumptions are required for the use of these estimators. First, in order to reach identification, the disturbances $\varepsilon_{i, t}$ must be serially uncorrelated. This is equivalent to having no second-order serial correlation in the firstdifferenced residuals, and can thus be directly tested in the first-differenced model. Second, the instruments must be uncorrelated with the first-differenced residuals, which can be tested using the Hansen test of overidentifying restrictions. ${ }^{23}$

Accordingly, it behooves us to instrument for all potentially endogenous and predetermined variables. In particular, we treat the lagged merger variables as endogenous (as the methodology of dynamic panel data prescribes), the stock market variable as endogenous, and the lagged antitrust actions and threshold variables as predetermined. First, event studies show that merger announcements - which are customarily followed by a merger notification may have a direct impact on stock markets (see Duso, Gugler \& Yurtoglu, 2006, 2007); thus, the stock-market variable may also be endogenous. Furthermore, lagged antitrust actions may sometimes be correlated with past merger notification shocks when an antitrust authority does not come to a definite decision in the same year as the merger notification. And finally, the OECD reports clearly state that merger thresholds have been changed in many countries in response to a rise in past merger notifications.

A downside of the proposed methodology, however, is that, although the number of valid moment conditions increases with the number of periods and these improve efficiency, the system GMM estimator may use too many moment conditions with respect to the number

\footnotetext{
${ }^{23}$ Additionally, the main assumption to use the augmented system estimator is that unobserved jurisdiction effects are uncorrelated with changes in the error term.
} 
of available observations. ${ }^{24}$ Put simply, too many instruments may lead to over-fitting the instrumented variables and bias the results. Therefore, it also behooves us to estimate - as a robustness check - our regression equation while only instrumenting for the clearly endogenous variables and while treating all other explanatory variables as exogenous. By doing so, we can keep the number of instruments relatively low and mitigate the over-fitting bias. Recall also that our employment of lagged antitrust actions as explanatory variables does mitigate the endogeneity problems with a contemporaneous relationship. Still, since our panel is relatively small, it could be that the efficiency gains from system GMM are also small. Therefore - keeping in mind that OLS, and Fixed and Random effects estimations potentially suffer from correlation between the (transformed) lagged dependent variables and the (transformed) error term, we also report these results.

Our main empirical results consist of six regression specifications that attempt to take the above issues into account. First, regressions’ \#1, \#2 \& \#3 respectively report the OLS, Random and Fixed effects estimation results—-where all three estimations include fixed period-specific effects. Regression \#4 reports the results of a GMM estimation where only the clearly-endogenous lagged dependent variables are instrumented for. Regression \#5 reports the results of a GMM estimation where the potentially-endogenous variables (lagged dependent variables and the Stock-Market variable) are instrumented for. Regression \#6 reports the results of a GMM estimation where the potentially-endogenous variables (lagged dependent variables and the Stock-Market variable) and the potentially-predetermined variables (Prohibitions, Remedies, and the Threshold variables) are instrumented for.

\section{EMPIRICAL RESULTS}

Table 2 reports the estimation results for the six regression specifications. Before we discuss the constructs of primary interest, we comment on the adequateness of the model in

\footnotetext{
${ }^{24}$ In cases where the number of instruments is large relative to the number of observations, system GMM results are biased toward those of OLS.
} 
all six regressions. All six estimations perform reasonably well in terms of model specification. First, the Hansen test of overidentifying restrictions yields evidence in all three GMM estimations (regressions` \#4, \#5 \& \#6) indicating that one cannot reject the hypothesis of no correlation between instruments and error terms. Second, the null hypothesis of no second order autocorrelation on the error differences cannot be rejected, suggesting that serial autocorrelation does not exist in the error terms (the smallest of all three estimations reports $\operatorname{Pr}>\mathrm{z}=0.555)$. Third, the R-squared terms in Regressions’ \#1 \& \#3 are relatively high at 0.96 \& 0.92 respectively, though largely a function of the regression model's dynamic nature. In short, the regression model seems to pass the necessary diagnostics and be well specified in terms of statistical significance. Before discussing the coefficients of primary interest, we comment here on the control variables:

The two lags of Mergers seem to be important variables. The first lag is positive and highly significant for all six estimations. While the second lag is insignificant - and negative - throughout, its inclusion appears appropriate as the negative sign allows for the eventual downturn in a merger wave. Further, we tested for and rejected the presence of a coefficient equal or higher than one concerning the sum of the two lagged Merger terms in all six specifications. $^{25}$

First, second, and third changes in thresholds ('Threshold1', 'Threshold2' and 'Threshold3') do not generally have a statistically robust effect on notified mergers in the regression equations. However, Threshold1 in regression \#3 (the fixed-effects estimation) does indicate the expected 'fewer merger notifications' in the years subsequent to the first change in a jurisdiction's threshold level. The overall insignificance might owe to the fact that dummies in a log-log specification measure a change in slope and not a change in intercepts (we would of course only expect threshold changes to impact intercept terms).

\footnotetext{
${ }^{25}$ We performed simple t-tests. Bond et al. (2005) showed that in panel data with relatively short panels, t-tests have good size properties and high power-even when series are potentially close to unit root. These properties are particularly valid in simple OLS and system GMM specifications.
} 
Important changes in antitrust laws ('Law1' and 'Law2') do not generally indicate a statistically significant impact over our period of study. Though as with threshold changes, the first law change in regression \#3 (the fixed-effects estimation) does involve statistical significance: where the first law change is followed by an increase in notified mergers in subsequent years. Since these are dummy variables in a log-log regression, the same comment applies as above with threshold changes. ${ }^{26}$ The EU 2004 Reform variable is significant and negative in four out of the six regression equations; thus, suggesting that the EU reforms generally led to fewer merger notifications in all the EU member antitrust jurisdictions.

The macroeconomic conditions (Growth) variable is significant and positive in regressions’ \#1 \& \#2; thus, yielding some support that economic growth generates merger waves. This result is in line with neo-classical theories on mergers that assume managers to maximize profits and mergers to become more profitable during economic booms (Lambrecht, 2004). Stock market conditions have a negative and significant impact on Mergers in regressions’ \#1 \& \#2 (the OLS \& Random Effects estimations). While this result is not in line with the behavioral literature on merger waves (where a higher stock market should lead to more mergers -- see Gugler, Mueller \& Yurtoglu, 2004, for an overview), the negative effect is not statistically robust throughout the six regression specifications.

We can now look at the causal relations between the variables of primary interest: the relationship between antitrust actions and merger frequencies: Prohibitions has a statistically-significant negative impact on future merger behavior in five out of the six regression equations (excluding only the OLS estimation in regression \#1). The consistent significance and strong impact of this variable suggests that spikes in the use of Prohibitions

\footnotetext{
${ }^{26}$ It appears then that law changes by themselves do not significantly impact merger behavior; instead, antitrust actions (the implementation of laws which we later discuss) seem to be key. The finding that only the enforcement of laws - not existence on the books - yields actual policy effects conforms with the existing literature (Boner \& Krueger, 1991). Furthermore, this might help explain why the literature on the impact of antitrust laws on price-cost margins finds inconclusive evidence.
} 
seem to send a very clear signal of toughness by antitrust authorities—a signal that significantly reduces future merger proclivities.

Remedies, on the other hand, seem to positively influence future Mergers; though, the coefficient estimate is only significant in three regression equations—regressions` \#1, \#2, \& \#4. Accordingly, we can interpret these results as suggesting that the effect of remedies coming at the expense of prohibitions (a lowering of antitrust toughness) is stronger than the effect of remedies coming at the expense of clearances (an increase in antitrust toughness). In other words, we have some evidence that firms seem to interpret spikes in remedies as indicating softer behavior on the part of antitrust authorities. Such an interpretation should be cautioned by the fact that the remedies coefficient estimate is not significant in the fixedeffects estimation (regression \#3); thus, suggesting that the remedies effect may only be capturing cross-jurisdictional variation. Nevertheless, the important point here is that the application of Remedies does not seemingly involve a significant deterrence effect.

Permitting a merger with the promise to monitor closely the future behavior of merging parties appears to send no signal to firms - the coefficient estimate (while mostly negative) is highly insignificant throughout our estimations. Accordingly, firms seem to not give any importance to Monitorings as an indication of the future tendencies of authorities.

In sum, the empirical results support the robustness of Prohibitions—-but not Remedies and Monitorings - in terms of deterrence effects. However, it is warranted to move beyond statistical significance and consider the economic significance that prohibitions may have on deterring future merger behavior. First off, the coefficient estimates for Prohibitions in Table 2 suggest that a 10\% spike in Prohibitions leads to a percentage drop in Mergers in the following year that ranges from $0.5 \%$ (Regressions’ \#1 \& \#2) to almost 1.6\% (Regression \#4). ${ }^{27}$ Consider the comparison between the US and the EU for more illustrative purposes: where the US stepped up prohibitions in 2002 (14 as compared to 9 in 2001) and the EU

\footnotetext{
${ }^{27}$ These results must be interpreted as an upper bound, however, since we transformed zeros to ones when going to the log specification.
} 
stopped prohibitions ( 0 as compared to 5 in 2001). Taking the conservative coefficient estimate from Regression \#2 suggests that the US faced almost 3.1 percent fewer mergers in 2003 due to the 2002 spike in Prohibitions, while the EU faced some 5.5 percent more mergers in 2003 due to the 2002 drop in Prohibitions. ${ }^{28}$ In short, the regression estimations generally support significant-and-robust deterrence effects for the application of Prohibitions.

\section{DISCUSSION AND CONCLUSION}

The deterrence effects of merger policy are generally an under-researched topic. The few studies in this area tend to focus on deterrence effects as manifested by mergers being shaped differently (composition-based deterrence), or as manifested by future price-cost margins (where it is difficult to disentangle regulatory from deterrence effects). Furthermore, few studies consider whether all the tools available for merger policy involve adequate deterrence. Accordingly, we focus on the impact of different merger-policy tools on frequency-based deterrence effects; we consider how different antitrust actions - prohibitions, remedies, and monitorings - influence the future proclivity of firms to engage in mergers. We bring empirical evidence to bear on this issue by employing a cross-jurisdictional data set for merger policies over the 1992-2005 period. The broad scope of our data allows consideration of whether changes in merger policy enforcement impact firms’ merger behavior.

Our empirical results suggest that antitrust actions can impact future merger frequencies; however, not all merger policy tools are effective deterrents. Prohibitions involve deterrence implications with respect to future merger frequencies, but both remedies - the most popular merger policy tool - and monitorings seem to involve no deterrence implications. The insignificant finding for monitorings does not greatly surprise, as they have

\footnotetext{
${ }^{28}$ Note that if we took the liberal coefficient estimate from Regression \#4; then, the US would face 8.8 percent fewer mergers in 2003 due to the 2002 spike in Prohibitions, while the EU would face 15.8 percent more mergers in 2003 due to the 2002 drop in Prohibitions. However, the coefficient estimate (-0.065) in Regression \#6 - where Prohibitions is also instrumented for - conforms more to the conservative coefficient estimates in Regressions’ \#1, \#2 \& \#3; hence, it appears most prudent to interpret the conservative results.
} 
generally been considered a weak merger policy tool in terms of regulatory effects; hence, few deem this tool able to involve serious deterrence effects. The findings for prohibitions and remedies, however, generate more serious implications.

First, the positive findings for prohibitions (where merger prohibition spikes lead to firms forsaking future merger proposals) suggest that antitrust actions can involve deterrence implications. While a small literature supports the existence of composition-based deterrence effects for merger policy, antitrust scholars and practitioners have generally needed to assume the existence of deterrence effects for merger policy, as it has been difficult to validate and quantify merger policy deterrence effects. Our empirical results suggest that merger policy at least in the form of prohibitions - not only involves composition-based deterrence but also frequency-based deterrence. Accordingly, antitrust authorities should appreciate that prohibitions carry an ability to deter the future proclivity of firms to seek mergers.

Second, the empirical findings for remedies suggest that this particular merger policy tool may not involve adequate deterrence. One should temper the implications from this finding, as we only consider frequency-based deterrence: put differently, remedies may still involve composition-based deterrence via the altering of how firms shape future merger proposals. Nevertheless, frequency-based deterrence is important in a world where antitrust authorities face budgetary and resource constraints. Therefore, our results imply that antitrust authorities should be cautious with regard to over-using remedies: remedies may indeed ameliorate the anti-competitive effects of proposed mergers, but such actions - unlike prohibitions - carry no robust negative effect on the future proclivity to merge.

We are not the first to suggest that remedies represent a weak merger policy tool; though, we are unique in citing the deterrence implications as a particular concern. A number of authors from different standpoints have criticized the effectiveness of remedies. Joskow (2002) argues that structural remedies are neither easy for authorities to apply nor easy for firms to adopt in light of the transaction costs involved. Joskow points out that many of the 
difficulties identified by the FTC (1999) study on divestitures - size not mattering, strategic behavior of divesting firms, information deficiencies of buying firms, and advisability of divesting on-going businesses versus assets - conform to a transaction cost economics perspective. Cabral (2003) claims that the interaction of divestitures with entry conditions may lead to unexpected outcomes: in particular, divestitures may make further entry unprofitable, thus leading to welfare-inferior market equilibria. Motta, Polo and Vasconcelos (2006) review a number of drawbacks that suggest remedies in the European context have not been effective; in particular, they suggest that remedies may act to enhance collusion. Furthermore, some empirical work finds remedies to generally be ineffective: Crandall and Winston (2003) find US consent decrees (namely, remedies) in two-digit SIC manufacturing industries to increase - not decrease - future price-cost margins; Duso, Gugler and Yurtoglu (2006, 2007) generally find second-phase European Commission remedies to not ameliorate anti-competitive effects. Hence, we proffer one additional criticism - weak deterrence - to the list of potential concerns regarding remedies.

In sum, we find prohibitions to be effective and remedies to be ineffective in the deterrence of future merger frequencies. The weak-deterrence implications of remedies may be a concern in light of the trend toward increased use of remedies as a merger policy tool. Justice William J. Brennan Jr. captured the underlining faith that has led to increased adoption of remedies when he states "Divestiture ... the most important of antitrust remedies. It is simple, relatively easy to administer, and sure". ${ }^{29}$ To the degree that antitrust authorities are concerned about the deterrence effects of merger policy, our results suggest that they may want to re-evaluate their penchant to increasingly employ remedies - instead of prohibitions to deal with anti-competitive merger proposals.

\footnotetext{
${ }^{29}$ See Parker and Balto (2000: p.5) for this quote.
} 


\section{REFERENCES}

Aaronson, Robin. 1992. Do companies take any notice of competition policy?. Consumer Policy Review 2(3): 140-145.

Arellano, Manuel and Olimpia Bover. 1995. Another Look at the Instrumental-Variable Estimation of Error-Component Models. Journal of Econometrics 68:29-52.

Arellano, Manuel, and Stephen Bond. 1992. Some Tests of Specification for Panel Data: Monte Carlo Evidence and an Application to Employment Equations. Review of Economic Studies 58:277-297.

Baker, Donald I. 2001. The Use of Criminal Law Remedies to Deter and Punish Cartels and Bid-Rigging. The George Washington Law Review 69: 693-714.

Baker, Jonathan B. 2003. The Case for Antitrust Enforcement. Journal of Economic Perspectives 17(4):27-50.

Barros, Pedro Pita 2003. Looking behind the curtain-effects from modernization of European Union competition policy. European Economic Review 47(4): 613-624.

Becker, Gary S. 1968. Crime and Punishment: An Economic Approach. Journal of Political Economy 76(2): 169-217.

Block, Michael Kent, Frederick Carl Nold, and Joseph Gregory Sidak. 1981. The Deterrent Effect of Antitrust Enforcement. Journal of Political Economy 89(3): 429-445.

Block, Michael Kent, and Jonathan S. Feinstein. 1986. The Spillover Effect of Antitrust Enforcement. Review of Economics and Statistics 68(1): 122-131.

Bond, Stephen. 2003. Dynamic Panel Data Models: A Guide to Micro Data and Practice. Portuguese Journal of Economics 1:141-162.

Bond, Stephen, Celine Nauges, and Frank Windmeijer. 2005. Unit Roots: Identification and Testing in Micro Panels. CEMMAP Working Paper CWP07/05.

Boner, RA, and R. Krueger. 1991. The basics of antitrust policy: a review of ten nations and the European Communities. World Bank Technical Papers, No. 160. World Bank:

Washington DC.

Cabral, Luis M.B. 2003. Horizontal Mergers With Free Entry: Why Cost Efficiencies May Be a Weak Defense and Asset Sales a Poor Remedy. International Journal of Industrial Organization 21: 607-623.

Clarke, Julian L., and Simon J. Evenett. 2003. The deterrent effects of national anticartel laws: evidence from the international vitamins cartel. Antitrust Bulletin Fall: 689-726.

Crandall, Robert W., and Clifford Winston. 2003. Does Antitrust Policy Improve Consumer Welfare? Assessing the Evidence. Journal of Economic Perspectives 17(4):3-26. 
Craswell, Richard, and John E. Calfee. 1986. Deterrence and Uncertain Legal Standards. Journal of Law, Economics and Organization 2(2): 279-303.

Davies, Stephen, and Adrian Majumdar. 2002. The Development of Targets for Consumer Savings Arising from Competition Policy. Working Paper No. 4. Office of Fair Trading, UK.

De Loecker, Jan, Joep Konings \& Patrick Van Cayseele, 2007. Merger Review: How Much of Industry is Affected in an International Perspective?” Journal of Industry, Competition and Trade, forthcoming.

Duso, Tomaso, Klaus Gugler, and Burcin Yurtoglu. 2006. How Effective is European merger Control?, Working Paper No. SP II 2006-12 Wissenschaftszentrum Berlin (WZB), Research Unit: Competitiveness and Industrial Change (CIC), Berlin, Germany.

Duso, Tomaso, Klaus Gugler, and Burcin Yurtoglu. 2007. EU Merger Remedies: An Empirical Assessment. in J. Stennek and V. Ghosal Eds., The Political Economy of Antitrust, Contributions to Economic Analysis, North-Holland, forthcoming.

Duso, Tomaso, Damien J. Neven, and Lars-Hendrik Röller. 2007. The Political Economy of Merger Control: Evidence using Stock Market Data. Journal of Law and Economics, forthcoming.

Dutz, Mark A., and Maria Vagliasindi. 2000. Competition policy implementation in transition economies: An empirical assessment. European Economic Review 44:762-772.

Eckbo, B. Espen, and Peggy Wier. 1985. Antimerger Policy under the Hart-Scott-Rodino Act: A Reexamination of the Market Power Hypothesis. Journal of Law and Economics 28(1):119149.

Eckbo, B. Espen. 1983. Horizontal Mergers, Collusion, and Stockholder Wealth. Journal of Financial Economics 11(1-4): 241-273.

Eckbo, B. Espen. 1989. The Role of Stock Market Studies in Formulating Antitrust Policy Towards Horizontal Mergers: Comment. Quarterly Journal of Business and Economics 28:22-38.

Eckbo, B. Espen. 1992. Mergers and the Value of Antitrust Deterrence. Journal of Finance 47(3): 1005-1029.

Ehrlich, Isaac. 1973. Participation in Illegitimate Activities: A Theoretical and Empirical Investigation. Journal of Political Economy 81(3): 521-565.

Feinberg, Robert F. 1980. Antitrust Enforcement and Subsequent Price Behavior. Review of Economics and Statistics 62(4): 609-612.

Fridolfsson, Sven-Olof, and Johan Stennek. 2005. Why Mergers Reduce Profits and Raise Share Prices - A Theory of Preemptive Mergers, Journal of the European Economic Association 3(5): 1083-1104.

Gugler, Klaus, Dennis Mueller, and Burcin Yurtoglu. 2004. The Determinants of Merger Waves. Working Paper No. 05-15, Utrecht School of Economics, Netherlands. 
Harford, Jarrod. 2005. What Drives Merger Waves?. Journal of Financial Economics 77(3):529-560.

Hoekman, Bernard, and Hiua Looi Kee. 2003. Imports, Entry and Competition Law as Market Disciplines. Working Paper No. 3031. World Bank Policy Research, Washington, DC. and Discussion Paper No. 3777. Center for Economic Policy Research, London, UK.

Joskow, Paul L. 2002. Transaction Cost Economics, Antitrust Rules, and Remedies. Journal of Law, Economics and Organization. 18(1): 95-116.

Kobayashi, Bruce H. 2002. Antitrust, Agency and Amnesty: An Economic Analysis of the Criminal Enforcement of the Antitrust Laws Against Corporations. Working Paper No. 02-04. George Mason University School of Law, Arlington, Virginia.

Konings, Jozef, Patrick Van Cayseele, and Frederic Warzynski. 2001. The Dynamics of Industrial Mark-ups in Two Small Open Economies: Does National Competition Policy Matter?. International Journal of Industrial Organization 19:841-859.

Lambrecht, Mark. 2004. The timing and terms of mergers motivated by economies of scale, Journal of Financial Economics 72(1): 41-62.

Motta, Massimo, Michele Polo, and Helder Vasconcelos. 2006. Merger Remedies in the European Union: An Overview, Antitrust Bulletin forthcoming.

OECD. 2003. Competition Policy in OECD Countries. OECD: Paris, France.

Owen, Bruce M. 2003. Competition Policy in Latin America. Working Paper No. 268. Stanford Institute for Economic Policy Research, Stanford, CA.

Parker, Richard, and David Balto. 2000. The Evolving Approach to Merger Remedies. Antitrust Report May: 2-28.

Pittman, Russel W. 1977. Market Structure and Campaign Contributions. Public Choice 31:37-58.

Posner, Richard A. 1970. A Statistical Study of Antitrust Enforcement. Journal of Law and Economics 13(2): 365-419.

Röller, Lars-Hendrik, Johan Stennek, and Frank Verboven. 2000. Efficiency Gains from Mergers. Working Paper No. FS IV 00-09. Wissenschaftszentrum Berlin (WZB), Research Unit: Competitiveness and Industrial Change (CIC), Berlin, Germany.

Sah, R. K. 1991. Social Osmosis and Patterns of Crime. Journal of Political Economy. 99(6): 1272-1295.

Spagnolo, Giancarlo. 2007. Leniency and Whistleblowers in Antitrust. In P. Buccirossi (ed.) Handbook of Antitrust Economics, Cambridge: MIT Press, forthcoming.

Stigler, George. 1966. The Economic Effects of the Antitrust Laws. Journal of Law and Economics 9: 225-258. 
Stillman, Robert. 1983. Examining Antitrust Policy Toward Horizontal Mergers. Journal of Financial Economics 11(1-4): 225-240.

U.S. Federal Trade Commission. 1999. A Study of the Commission's Divestiture process. (http://www.ftc.gov/opa/1999/08/divestreport.htm).

Van Eden, Holger. 2002. Fighting Hard Core Cartels: Harm, Effective Sanctions and Leniency Programmes, Paris: OECD.

Warzynski, Frederic. 2001. Did Antitrust Policy Lead to Lower Mark-Ups in the US Manufacturing Industry?. Economics Letters 70:139-144.

Werden, Gregory J., and Michael A. Williams. 1989. The Role of Stock Market Studies in Formulating Antitrust Policy Toward Horizontal Mergers. Quarterly Journal of Business and Economics 28(4): 3-21. 
Figure 1: The Average Across All Antitrust Jurisdictions of the Ratio of 'Remedies to Prohibitions'

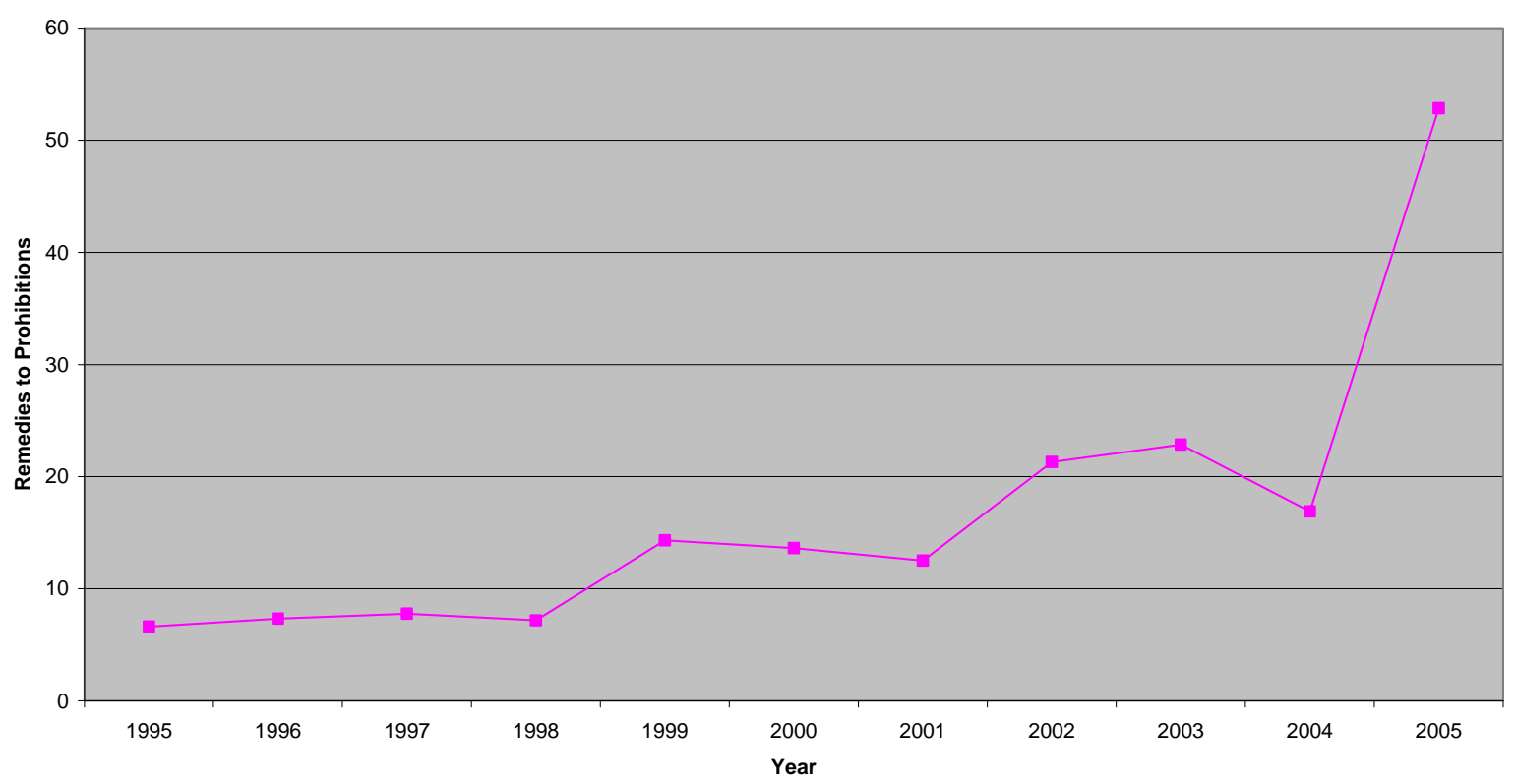


Figure 2: The Average Across All Antitrust Jurisdictions for the Number of 'Antitrust actions' and 'Mergers'

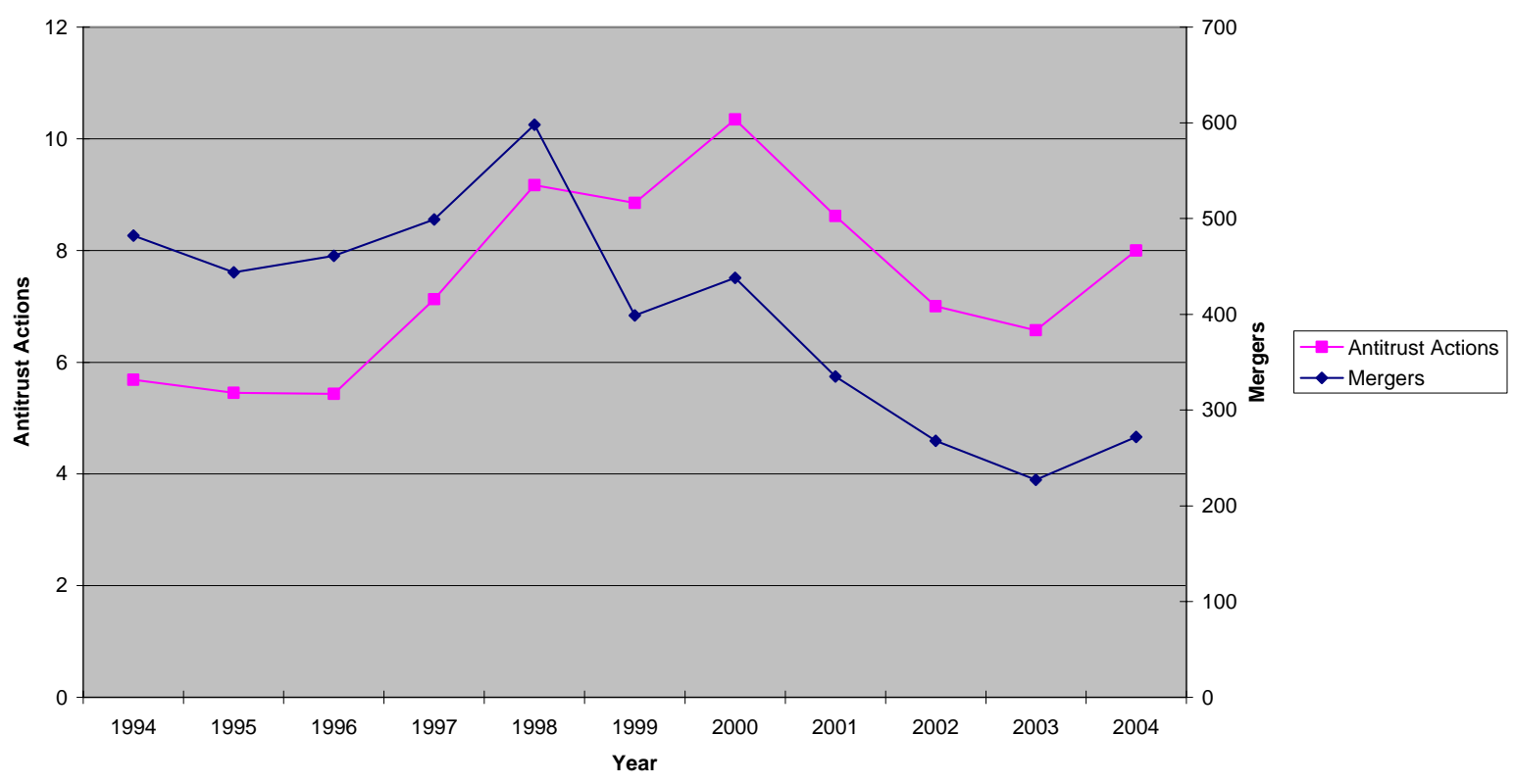


Figure 3: The Average Across All Antitrust Jurisdictions of the Percentage of 'Notified Mergers Eliciting Antitrust Actions'

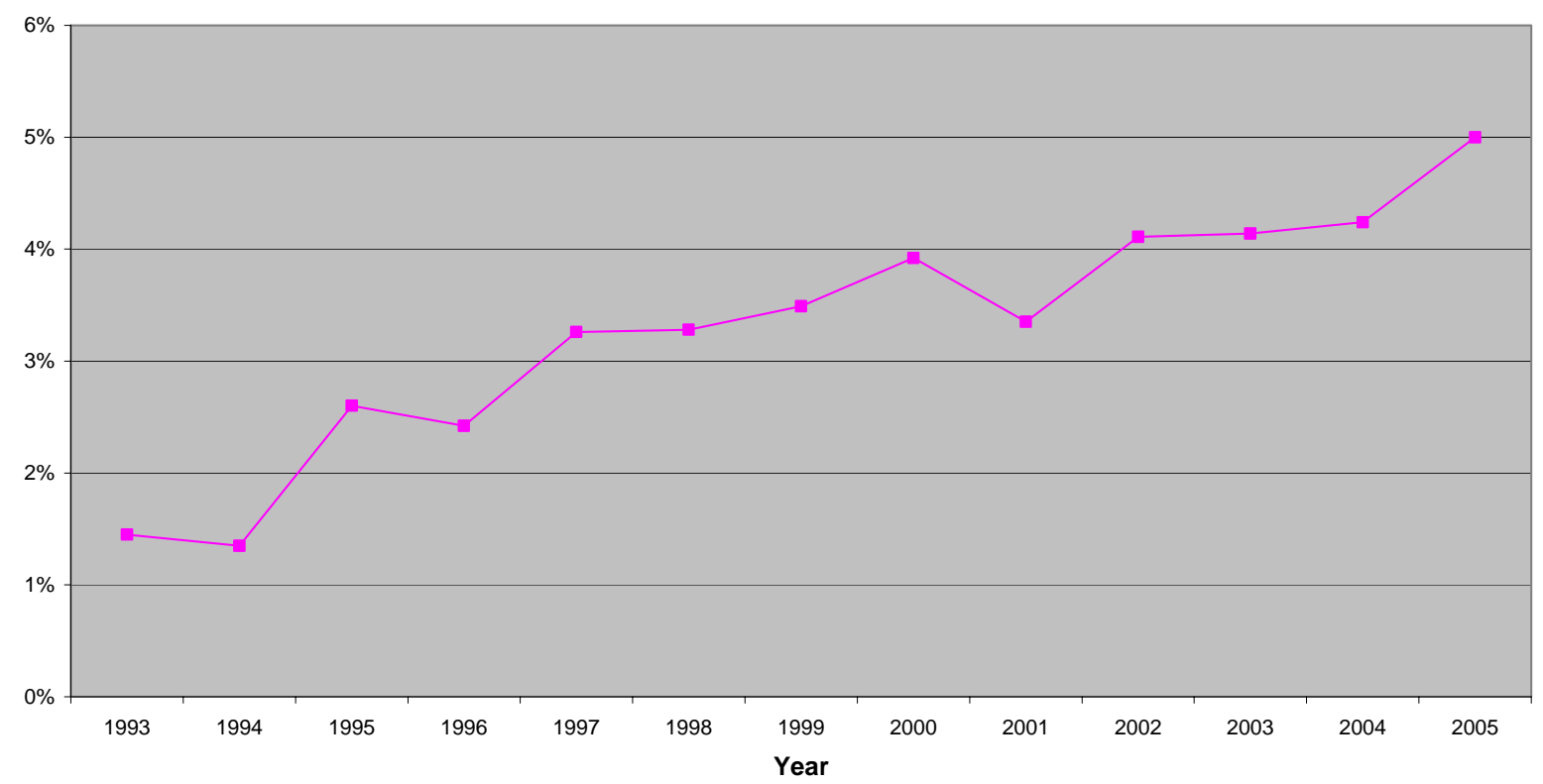




\begin{tabular}{|c|c|c|c|c|c|}
\hline & & & Variab & Means & \\
\hline $\begin{array}{l}\text { Antitrust } \\
\text { Jurisdiction }\end{array}$ & $\begin{array}{l}\text { Observation } \\
\text { Numbers }\end{array}$ & Mergers & Prohibitions & $\underline{\text { Remedies }}$ & Monitorings \\
\hline Australia & 9 & 200.4 & 3.7 & 4.9 & 0.2 \\
\hline Austria & 5 & 241.2 & 0 & 2.8 & 0 \\
\hline Belgium & 6 & 48.3 & 1.1 & 0.2 & 0.2 \\
\hline Brazil & 6 & 563.7 & 0.3 & 10.5 & 0 \\
\hline Canada & 11 & 288.3 & 0.3 & 3.9 & 0.6 \\
\hline Czech Republic & 9 & 113.9 & 1.4 & 4.2 & 0 \\
\hline Denmark & 4 & 44.8 & 0 & 1 & 0 \\
\hline European Union & 12 & 230.7 & 1.5 & 15.3 & 0 \\
\hline Finland & 5 & 81.6 & 0.2 & 2.8 & 0 \\
\hline France & 4 & 497.8 & 0 & 2.5 & 0 \\
\hline Germany & 11 & 1415.8 & 3.6 & 5.9 & 0 \\
\hline Greece & 2 & 83.5 & 1 & 0 & 0 \\
\hline Hungary & 9 & 62.2 & 0.3 & 1.2 & 0 \\
\hline Ireland & 7 & 229.3 & 0.3 & 0.1 & 0 \\
\hline Italy & 10 & 499.3 & 0.6 & 2.4 & 0 \\
\hline Mexico & 7 & 244.3 & 1.9 & 7 & 0 \\
\hline Netherlands & 5 & 112.2 & 0.2 & 1.6 & 0 \\
\hline New Zealand & 9 & 76.8 & 3.4 & 2 & 0 \\
\hline Norway & 7 & 35.9 & 0.3 & 1.9 & 0.1 \\
\hline Poland & 3 & 498.7 & 0.4 & 1 & 0 \\
\hline Portugal & 6 & 42.5 & 0 & 0.2 & 0.3 \\
\hline Slovenia & 12 & 60.2 & 0.4 & 0.8 & 0 \\
\hline Spain & 8 & 67.9 & 0.4 & 3.4 & 0 \\
\hline Sweden & 10 & 135.6 & 0.6 & 1.6 & 0 \\
\hline Switzerland & 6 & 37.8 & 0 & 1 & 0 \\
\hline Turkey & 5 & 117.4 & 0.4 & 1.8 & 0 \\
\hline United Kingdom & 10 & 379.5 & 2.3 & 5.7 & 0.2 \\
\hline United States & 11 & 2766.4 & 15.2 & 43 & 0 \\
\hline All Jurisdictions & 209 & 390.5 & 1.8 & 5.8 & 0.1 \\
\hline
\end{tabular}




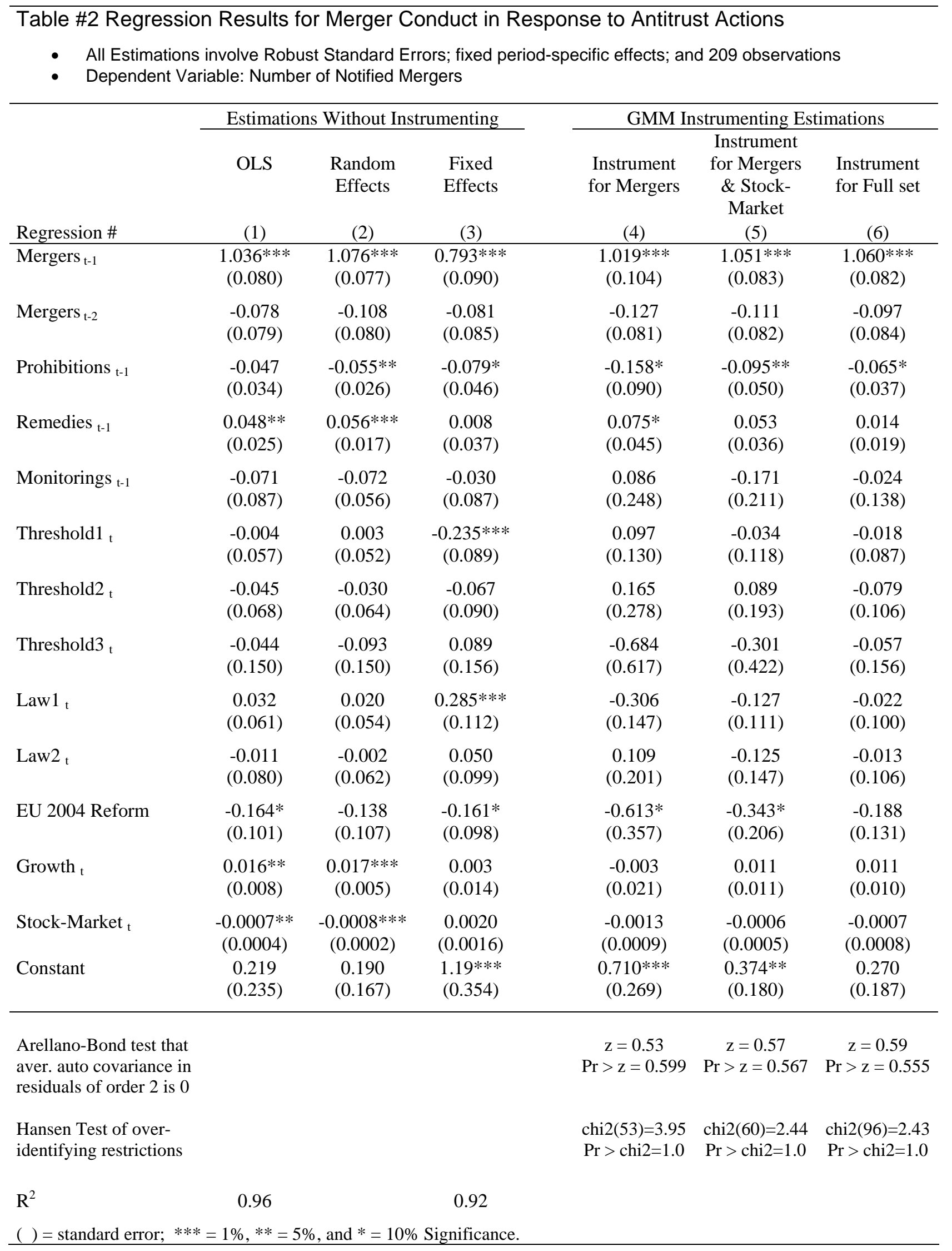


Bücher des Schwerpunkts Märkte und Politik

Books of the Research Area Markets and Politics

Kai A. Konrad, Beate Jochimsen (Eds.)

Finanzkrise im Bundesstaat

2006, Peter Lang Verlag

Robert Nuscheler

On Competition and Regulation in Health Care

Systems

2005, Peter Lang Verlag

Pablo Beramendi

Decentralization and Income Inequality

2003, Madrid: Juan March Institute

Thomas Cusack

A National Challenge at the Local Level: Citizens, Elites and Institutions in Reunified Germany

2003, Ashgate

Sebastian Kessing

Essays on Employment Protection

2003, Freie Universität Berlin

http://www.diss.fu-berlin.de/2003/202

Daniel Krähmer

On Learning and Information in Markets and

Organizations

2003, Shaker Verlag

Tomaso Duso

The Political Economy of the Regulatory Process:

An Empirical Approach

Humboldt-University Dissertation, 2002, Berlin,

http://edoc.hu-berlin.de/dissertationen/duso-tomaso-

2002-07-17/PDF/Duso.pdf

Bob Hancké

Large Firms and Institutional Change. Industrial

Renewal and Economic Restructuring in France

2002, Oxford University Press

Andreas Stephan

Essays on the Contribution of Public Infrastructure to Private: Production and its Political

Economy

2002, dissertation.de

Peter A. Hall, David Soskice (Eds.)

Varieties of Capitalism

2001, Oxford University Press

Hans Mewis

Essays on Herd Behavior and Strategic Delegation 2001, Shaker Verlag

Andreas Moerke

Organisationslernen über Netzwerke - Die personellen Verflechtungen von Führungsgremien japanischer Aktiengesellschaften

2001, Deutscher Universitäts-Verlag

Silke Neubauer

Multimarket Contact and Organizational Design

2001, Deutscher Universitäts-Verlag
Lars-Hendrik Röller, Christian Wey (Eds.)

Die Soziale Marktwirtschaft in der neuen

Weltwirtschaft, WZB Jahrbuch 2001

2001, edition sigma

Michael Tröge

Competition in Credit Markets: A Theoretic

Analysis

2001, Deutscher Universitäts-Verlag

Torben Iversen, Jonas Pontusson, David Soskice

(Eds.)

Unions, Employers, and Central Banks

2000, Cambridge University Press

Tobias Miarka

Financial Intermediation and Deregulation:

A Critical Analysis of Japanese Bank-Firm-

Relationships

2000, Physica-Verlag

Rita Zobel

Beschäftigungsveränderungen und organisationales Lernen in japanischen

Industriengesellschaften

2000, Humboldt-Universität zu Berlin

http://dochost.rz.hu-berlin.de/dissertationen/zobel-rita2000-06-19

Jos Jansen

Essays on Incentives in Regulation and Innovation 2000, Tilburg University

Ralph Siebert

Innovation, Research Joint Ventures, and

Multiproduct Competition

2000, Humboldt-Universität zu Berlin

http://dochost.rz.hu-berlin.de/dissertationen/siebertralph-2000-03-23/

Damien J. Neven, Lars-Hendrik Röller (Eds.)

The Political Economy of Industrial Policy in

Europe and the Member States

2000, edition sigma

Jianping Yang

Bankbeziehungen deutscher Unternehmen:

Investitionsverhalten und Risikoanalyse

2000, Deutscher Universitäts-Verlag

Christoph Schenk

Cooperation between Competitors -

Subcontracting and the Influence of Information, Production and Capacity on Market Structure and Competition

1999, Humboldt-Universität zu Berlin

http://dochost.rz.hu-berlin.de/dissertationen/schenkchristoph-1999-11-16 
Klaus Gugler

Dennis C. Müller

B. Burçin Yurtoglu

Augusto R. Micola Albert Banal Estañol

Derek W. Bunn

Benny Geys

Thomas R. Cusack

Ela Glowicka

Benny Geys

Benny Geys Bruno Heyndels

Johannes Münster

Johannes Münster

Kjell Erik Lommerud

Steinar Vagstad

Hilde Coffé

Benny Geys

Tomaso Duso

Klaus Gugler

Burçin Yurtoglu

Erkki Koskela

Ronnie Schöb

Derek Clark

Kai A. Konrad

Brian Roberson

Jonathan Beck

Albert Banal-Estañol

Paul Heidhues

Rainer Nitsche

Jo Seldeslachts

Susanne Prantl
The Determinants of Merger Waves

SP || $2006-01$

Incentives and Cooperation in Vertically Related

SP || $2006-02$

Energy Markets

Looking across Borders: A Test of Spatial Policy Interdependence using Local Government Efficiency Ratings

SP II $2006-03$

SP II $2006-04$

Sinking Budgets and Ballooning Prices: Recent

Developments Connected to Military Spending

Effectiveness of Bailouts in the EU

SP II $2006-05$

SP || $2006-06$

Local Public Debt:

Evidence from Flemish Municipalities

Disentangling the Effects of Political

SP || $2006-07$

Fragmentation on Voter Turnout: The Flemish

Municipal Elections

Selection Tournaments, Sabotage, and

SP || $2006-08$

Participation

Contests with Investment

SP || 2006- 09

Mommy Tracks and Public Policy: On Self-Fulfilling

Prophecies and Gender Gaps in Promotion

Towards an Empirical Characterization of Bridging

and Bonding Social Capital

How Effective is European Merger Control?

SP I| $2006-10$

SP || $2006-11$

SP || $2006-12$

Tax Progression under Collective Wage Bargaining SP || $2006-13$

and Individual Effort Determination

Contests with Multi-Tasking

SP || $2006-14$

SP || $2006-15$

Fiscal Federalism

The Sales Effect of Word of Mouth: A Model for

Creative Goods and Estimates for Novels

SP || $2006-16$

SP || $2006-17$

Merger Clusters during Economic Booms

SP || $2006-18$

The Role of Policies Supporting New Firms: An Evaluation for Germany after Reunification 
Tomaso Duso

Klaus Gugler

Burçin Yurtoglu

Michał Grajek Tobias Kretschmer

Susanne Prantl Matthias Almus Jürgen Egeln Dirk Engel

Joseph A. Clougherty Michał Grajek

Kjell Erik Lommerud Frode Meland Odd Rune Straume

Kjell Erik Lommerud Trond E.Olsen Odd Rune Straume

Paul Heidhues Botond Kőszegi
Is the Event Study Methodology Useful for Merger Analysis? A Comparison of Stock Market and Accounting Data

Usage and Diffusion of Cellular Telephony, 19982004

Bankintermediation bei der Kreditvergabe an junge oder kleine Unternehmen

The Impact of ISO 9000 Diffusion on Trade and FDI A New Institutional Analysis

Can Deunionization Lead to International Outsourcing?

Cross-Border Mergers and Strategic Trade Policy with Two-Part Taxation: Is International Policy Coordination Beneficial?

Competition and Price Variation when Consumers are Loss Averse
SP || $2006-19$

SP || $2006-20$

SP || $2006-21$

SP || $2006-22$

SP || $2006-23$

SP || $2006-24$

SP II $2006-25$ 
DISCUSSION PAPERS 2007

Kai A. Konrad Strategy in Contests - an Introduction

Jo Seldeslachts Joseph A. Clougherty

Pedro Pita Barros
Remedy for Now but Prohibit for Tomorrow: The Deterrence Effects of Merger Policy Tools
SP I| $2007-01$

SP || $2007-02$ 
Bei Ihren Bestellungen von WZB-Papers schicken

Sie bitte unbedingt einen an Sie adressierten Auf-

kleber mit sowie je paper eine Briefmarke im Wert

von 0,51 Euro oder einen "Coupon Reponse Inter-

national " (für Besteller aus dem Ausland)
Please send a self addressed label and postage stamps in the amount of 0.51 Euro or a "CouponReponse International" (if you are ordering from outside Germany) for each WZB-paper requested

Absender I Return Address:

Wissenschaftszentrum Berlin

für Sozialforschung

Presse- und Informationsreferat

Reichpietschufer 50

D-10785 Berlin-Tiergarten

Hiermit bestelle ich folgende(s)

Discussion paper(s):

Please send me the following Discussion paper(s):

Bestell-Nr. I Order no.

Autor/in, Kurztitel /Author(s) / Title(s) in brief 